Dicle University Journal of Engineering (DUJE)

web: http://dergipark.gov.tr/dumf

Derleme Makalesi / Review Article

\title{
Gelişmekte Olan ve Gelişmiş Ülkelerde Yüksek Hızlı Demiryolu Yatırım Kriterlerinin İncelenmesi
}

\section{A Review of High Speed Railway Investment Criterias in Developed and Developing Countries}

\author{
Mehmet Fatih Altan $^{1 *}$, Mehmet Çağrı Kızıltaş², Yunus Emre Ayözen ${ }^{3}$ \\ ${ }^{1}$ İstanbul Aydin Üniversitesi, İnşaat Mühendisliği Bölümü, İstanbul, mehmetaltan@aydin.edu.tr

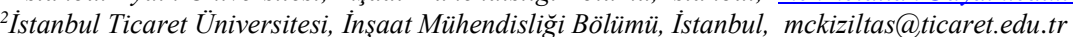 \\ ${ }^{3}$ Devlet Hava Meydanları Iş̧letmesi Genel Müdürlüğü, Ankara, yunusemre.ayozen@dhmi.gov.tr
}

\begin{tabular}{|c|c|}
\hline \multicolumn{2}{|c|}{ MAKALE BİLGİLERİ } \\
\hline \multicolumn{2}{|c|}{ Makale geçmişi: } \\
\hline Geliş: & 27 Haziran 2019 \\
\hline Düzeltme: & 5 Temmuz 2019 \\
\hline Kabul: & 8 Ağustos 2019 \\
\hline
\end{tabular}

Altyapı, yüksek hızlı demiryolları, gelişmişlik seviyesi, türel dă̆ı̆lım, ulaşım altyapıları

\begin{abstract}
ÖZET
Altyapı yatırımları gelișmiș olan ülkelerin yıllık bütçesinden az bir pay almakradır. Zira bu ülkeler altyapı kurulum süreçlerini büyük ölçüde tamamlamışlardır. Gelişmemiş olan ülkelerde de altyapı yatırımlarının yıllık bütçeden aldığı pay düşüktür. Çünkü bu ülkeler muhtelif büyüme unsurlarını ekonomik güç ile teşvik edemediklerinden dolayı önemli altyapı yatırırmlarına girişemezler. Gelişmekte olan ülkelerde ise altyapı yatırımlarının yıllık bütçeden aldığı pay yüksektir. Bu ükelerde nüfus büyümekte, kentleşme artmakta, hem arz ve hem de talep yükselmektedir. Ekonomik büyüme eğilimi de söz konusudur. Dolayısı ile altyapı büyümesi de ekonomik büyüme ve ülkenin büyümesi ile eş güdümlü götürülmeye çalışılmaktadır. Bu nedenle yoğun bir altyapı kurulum süreci yaşanmaktadır. Bu çalışmada ilk olarak yüksek hızlı demiryolları ve yeni penetre olduğu bir sistemdeki gelişim kriterleri ele alınmıştır. Ardından ise bu tür için koridor seçim esasları ortaya konulmuştur. Sonrasında çok sayıdaki ülke üzerinden küresel karşılaştırmalar yapılmıştır. Son olarak da sonuç ve öneriler paylaşılmıştır.
\end{abstract}

Doi: $10.24012 /$ dumf.667374

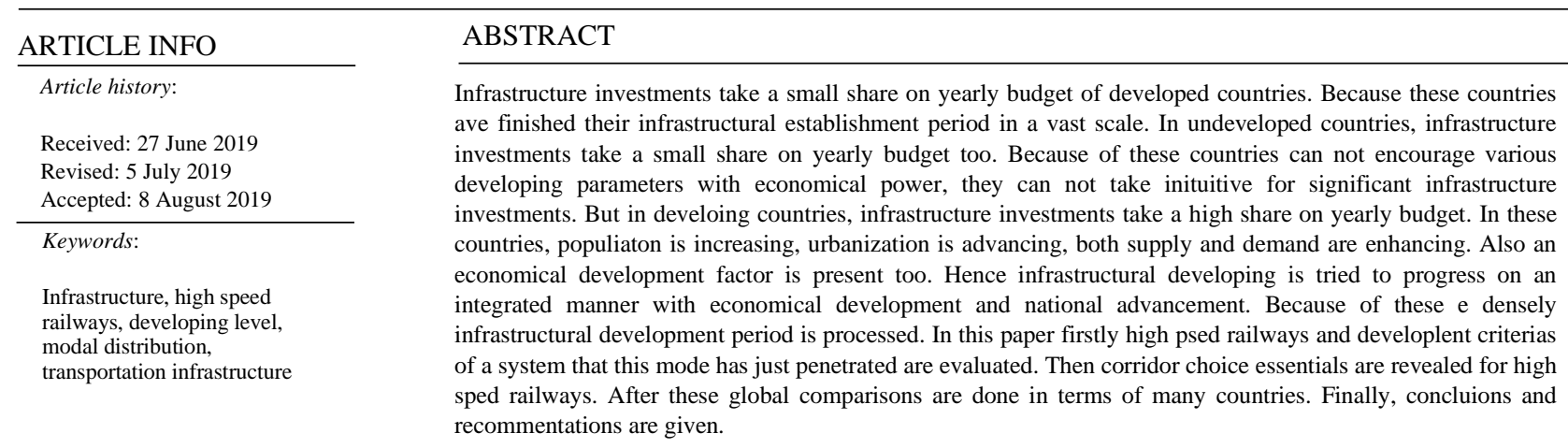

* Sorumlu yazar / Correspondence

Mehmet Fatih ALTAN

$\triangle$ mehmetaltan@ticaret.edu.tr 


\section{Giriș}

Günümüzde kimi çalışmalarda demiryolu sistemi üzerine yoğunlaşmak yerine otomobil ve havayolu ulaştırma türlerinin geliştirilmesi ile ilgilenilmektedir. Fakat kullanıcı davranışları ele alındığında bir yolculuk tercihinde sadece teknik imkânlar değil aynı zamanda sosyal eğilimlerinin de etkili olduğu görülecektir. Eğer sosyal dinamiklerin demiryolu ulaştırmasının gelişimine adaptasyonu söz konusu olursa yüksek hızlı demiryolları modern ulaştırma sisteminde öncül bir konuma gelebilir. Bu yönde çalışmalara odaklanılması için fazlası ile gerekçe bulunmaktadır. Çelik tekerlekli demiryolları etkili ve doğrudan bir hizmet sunmaktadır. Yüksek hızlı demiryolları 50 yıllık bir deneyime sahip olup küresel ölçekte yaygınlık kazanmış bir ulaştırma türüdür. $\mathrm{Bu}$ çalışma kapsamında öncelikle Avrupa Birliği ölçeğinde yüksek hızlı demiryollarının konumu ele alınmış, ardından Almanya ve Birleşik Krallık örnekleri incelenmiş, akabinde de bu ulaştırma türü odağında bir Amerika Birleşik DevletleriAvrupa Birliği kıyası sunulmuştur. Son olarak da küresel ölçekte yüksek hızlı demiryolunda olması gerekenler ile ilgili çıkarımlar yapılmıştır. $\mathrm{Bu}$ çalışmanın amacı küresel ölçekteki gelişme eğilimleri üzerinden yüksek hızlı demiryollarının oluşum sürecini tartışmaktır [1].

Yüksek hızlı demiryolları ilk defa Japonya'da ortaya çıktığımızdan bugüne 50 yılı aşkın bir deneyime ulaşmıştır. Söz konusu ulaştırma türü erken dönem ileri düzey örneklerini Japonya, Fransa ve Almanya'da ortaya koymuştur. Takip eden yıllarda ise İtalya, İsveç, Birleşik Krallık, Güney Kore, İspanya ve Rusya gibi ülkeler sürece dâhil olmaya başlamıştır. 2000'li yıllar ile birlikte İspanya ve Çin'in yüksek hızlı demiryollarındaki (YHD) muazzam yükselişine şahitlik edilmiştir. Günümüz itibari ile sektörün liderleri olarak Japonya, İspanya, Fransa ve Çin zikredilmektedir. Türkiye'nin de 2000'li y1llar ile birlikte sektöre dâhil olması ve hızlı ilerleyişi söz konusudur. Bahsi geçen ülkelerin hemen hepsi bir şekilde yüksek hızlı demiryollarına (YHD) sahiptir. Hatta bu liste mevcut durumda Cezayir, Arjantin, Suudi Arabistan, Meksika, Singapur, Tayvan, Amerika Birleşik Devletleri (ABD), Özbekistan ve İran gibi ülkeler ile de uzatılabilir. Ancak bu noktada henüz yüksek hızlı demiryollarının tek bir tanımına tam anlamı ile ulaşılamamıştır. Altyapı, hı, hizmet parametreleri, işletim şekilleri vb. değerlendirme kıstaslarına göre önemli farklılıklar oluşabilmektedir. Dolayısı ile bu noktada yüksek hızlı demiryollarının da (YHD) kendi içerisinde, ülkeler üzerinden karşılaștırmalı değerlendirmeler ile önceliklere göre nasıl değerlendirilmesi gerekliliği noktasında bir ölçüt geliştirilmelidir. $\mathrm{Bu}$ çalışma kapsamında bu gereksinim yolunda bir ilk adım atılmaya çalışılmaktadır [2]. Almanya'daki yüksek hızlı tren işletimeri ise kentler arası yüksek hız anlamını taşıyan ICE tarafindan gerçekleştirilmektedir. Almanya'da hatlar kimi yerlerde doğu batı akslı olmakla beraber esasen kuzey güney akslı baskın bir karaktere sahiptir. Ana hat eksenleri ise Frankfurt, Hamburg, Berlin, Köln ve Münih odaklı olaraktan dağılmaktadır. Yolcu ulaşımının yük taşınmasından çok daha öncelikli halde olması, demiryolu politikları ekseninde Avrupa Birliği (AB) için aksayan bir yön olarak telakki edilmekte olup Amerika Birleşik Devletleri (ABD) için kentler arası yolcu ulaşımında demiryolu türel dağılım oranı sadece $\% 0,32$ 'lerde iken Avrupa Birliği için ise bu değer $\% 6,25$ 'lerdedir.

Avrupa Komisyonu'nun 2001 Beyaz Kitap'1nın ana hedeflerinden biride bu konudur. Fakat bütün bu değişimler ve projeksiyonlar dâhilinde, orta vadede Avrupa Birliği'nin (AB), yük taşımacılığında A.B.D.'nin \%38'lik türel dağılım payına ulaşması mümkün görülmemektedir [3]. Kilometre başına maliyet, 4 milyon $\$$ olarak konmuş ve halen en pahalı Fransız yatırımları 1015 milyon \$'lar seviyesinde gerçekleşiyor olup 
bu, İtalya'nın 25 milyon $\$ / \mathrm{km}$ ve Birleşik Krallık'ın 74 milyon $\$ / \mathrm{km}$ (Kanal Tünel Demiryolu Ağı İlk Fazı) maliyetlerinin yanında oldukça uygundur. Tablo 1'de ülkelerin karşılaştırmalı yüksek hızlı demiryolları (YHD) yapım maliyetleri ortaya konmuştur. Şekil 1'de ise seyahat süreleri ile yüksek hızlı demiryolu (YHD) türel dağılım payı arasındaki ilişki gösterilmektedir [4].

Tablo 1. Yüksek hızlı demiryolları (YHD) yapım maliyetleri [4]

\begin{tabular}{lc}
\hline & $\begin{array}{r}\text { YHD Yapım Maliyetleri } \\
\text { (km başına milyon A.B.D. Doları) }\end{array}$ \\
\hline Fransa ve İspanya & 10 \\
\hline Belçika ve Almanya & 15 \\
\hline İtalya & 25 \\
\hline Hollanda & 53 \\
\hline Britanya & 74 \\
\hline Tayvan & 37 \\
\hline Güney Kore & 37 \\
\hline
\end{tabular}

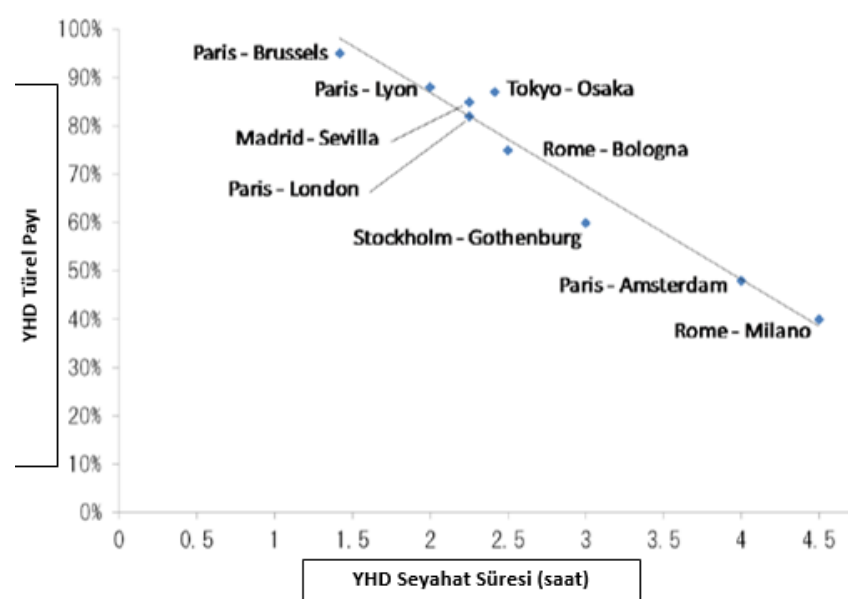

Şekil 1: Seyahat Süresi ve Yüksek Huzlı Demiryolunun Türel Payı Arasındaki İlişki [5]

$\mathrm{Bu}$ noktada, kentteki istasyonuna erişen bir yüksek hızlı trenin taşıdığı yolcuların, istasyonun bulunduğu noktadan kentin içine aktarımları da önemli bir noktadır. Bunun için, kentteki yüksek hızlı demiryolu (YHD) garı ile entegre bir ulaştırma hizmetinin kurulumu zaruridir. $\mathrm{Bu}$ açıdan garın merkezi konumdaki bir odak olarak teşekkülü belirleyici olacaktır. Yüksek hızlı demiryolu (YHD garları; büyük aktarma merkezi, alışveriş mekânı, dinlenme, gıda transferi ve benzeri işlevlerin doğrudan ya da dolaylı bir sağlayıcısı konumunda olmalıdır. İnsanlar söz konusu garlarda, hâlihazırdaki havalimanlarından da daha fazla zaman harcama eğilimlerini karşılayabilmelidirler. Bu anlamıyla garlar kente açılan ana kapılar olarak algılanabilir. Bunun devamı olarak, kimi yüksek hızlı demiryolu (YHD) garlarına kentler aras1 otobüs hatlarının da uğraması temin edilmelidir. Türkiye gibi ülkeler için kentler arası otobüs ve yüksek hizlı tren seferlerinin entegrasyonu önemli bir noktadır. Demiryolu istasyonlarının çevresinde oluşan banliyölerde olduğu gibi, önümüzdeki on yıllarda da yüksek hızlı demiryolu (YHD) garı çevresindeki şekillenme olgusu ile karşılaşılabilir. Bunun alacağı şekli bugünlerde alınacak kararlar tayin edecektir [5].

\section{Materyal ve Yöntem}

\section{Aday Koridor Seçimine İlişkin Göstergeler}

Mesafe ve seyahat süresi; yüksek hızlı demiryolu koridoru tanımlanmasında önemli kriterlerdendir. Seyahat süresi yaklaşık 4 saati aştığında, yüksek hızlı demiryollarının türel dağılımdaki payı \%50'nin altına düşmektedir. Yüksek hızlı trenlerin rekabetçiliğini arttırmak için; seyahat süresinin 4 saatin altına düşürülmesi istenmektedir [6].

Örneğin 300 km/saat işletim hızına göre planlanmış bir yüksek hızlı tren; tarifeli işletimde $200 \mathrm{~km} / \mathrm{saat}$ ile işletilmektedir. Bu kabule göre; bir yüksek hızlı tren için maksimum işletim mesafesi $800 \mathrm{~km}$ olarak öngörülebilir. Ayrıca; dakiklik ve hava şartlarına bağlı değişimlere karşı dayanıklılık başta olmak üzere yüksek hızlı demiryollarında gelecek dönemlerde sağlanacak olan teknolojik gelişmelerle $1000 \mathrm{~km}$ mesafelere kadar bu ulaştırma türü avantajlı hale gelecektir [6].

Yüksek hızlı trenlerin fizibilitesi; trafik hacimleri ile doğrudan ilintilidir. Örneğin; Mart 2011'de 
Tokaido Shinkansen bir günde 341 tren işleterek 378.000 yolcu taşıdı. Ayrıca; diğer bazı Shinkansen hatları da taşıdığı yolcu bakımından dünyanın en büyük demiryolları arasındadır. $\mathrm{Bu}$ Shinkansen hatları, ilk açıldıklarında bu kadar yüksek rakamlarda yolcu taşımıyorlardı. Mevcut trafik hacmi; işletime başlanan günden buyana kademeli artışın bir sonucu olup ilk işletildiğinde bugüne kıyasla oldukça düşük rakamlarda taşıma gerçekleştirilmiştir. Ayrıca; Tokaido Shinkansen ilk işletime başladığında 2 tren/saat işletim kapasitesine sahipken bugün bu oran saatte 10 trenin üzerine çıkmıştır. Bu; gelişmekte olan ülkelerde yüksek hızlı demiryolu kurulumu için, gelişmiş ülkelerin mevcutta sahip olduğu yüksek hızlı demiryolu hatlarının trafik hacimlerinden çok, bu ülkelerin ilk yüksek hızlı demiryolu kurulumuna geçiş süreçlerindeki trafik verilerinin yol gösterici olacağı anlamına gelmektedir. Ayrıca her bir güzergâhtaki toplam yolcu sayısının hesaplanması ya da tahmininde şehirlerarası OD trafik hacimlerinin bilinmesi gereklidir. Sonuç olarak; şehirlerarası trenlerin etkili olduğu yıllarda, yani Tokaido Shinkansen'in açılışından günümüze, taşınan yolcu sayıs1 1962'den günümüze yıllık veri toplayan Bölgeler Arası Hareketlilik Araştırmalarından elde edilmiştir [7]. Bununla beraber; Bölgeler Arası Hareketlilik Araştırmaları, sadece Tokaido Shinkansen' in taşıdığı yolcu ile ilgili değil diğer - özellikle kısa mesafeli - bölgesel trenlerle ilgili de bilgi toplamaktadır. Buna örnek olarak, aynı şehir için içerisinde ya da komşu şehirlerarasında çalışan trenlerce taşınan yolcu sayısı ya da günlük ev-iş, ev-okul yolculukları ile ilgili bilgiler verilebilir. $\mathrm{Bu}$ nedenle; yeterli mesafedeki şehirlerarasında insanlar Shinkansen ya da ekspres trenleri gibi daha üst düzey trenleri tercih etmekte ve bu yolculuklar beraber, günlük olmayan tatil ve iş yolculuklarının verileri de analizlerde değerlendirilmiştir. 1962 ve 2009 yıllarındaki şehirlerarası hatlar ve bunların trafik hacimleri Tablo 2'de verilmiştir [7].
Tablo 2. 1962 ve 2009 Yıllarında Şehirler Arası Trenlerin Taşıdığı Yolcu Sayısı [7]

\begin{tabular}{lcc}
\hline Hat & 1962'de Yolcu & 2009'da Yolcu \\
\hline Tokyo-Aichi & 5458 & 20.633 \\
\hline Tokyo-Osaka & 6105 & 20.596 \\
\hline Osaka-Hiroshima & 1707 & 4550 \\
\hline Osaka-Fukuoka & 900 & 4313 \\
\hline Tokyo-Miyagi & 2136 & 8755 \\
\hline Tokyo-Niigata & 3452 & 9196 \\
\cline { 2 - 3 } tek yönde günlük yolcu sayıs &
\end{tabular}

1962'deki rakamlara bakıldığında, Tokaido Shinkansen açılmadan önce, Tokyo-Aichi arasında yaklaşık 5500 ve Tokyo-Osaka arasında yaklaşık 6100 yolcu taşındığı görülmektedir. Bu rakamlar, günümüzde aynı hatta taşınan yolcu sayılarının 3'te 1'i, 4'te 1'i kadardır. Daha önce de belirtildiği üzere bu yerel hatlarda oluşan yüksek talep üzerine Tokaido Shinkansen inşa edilmiştir. Diğer bir deyişle, bu yerel hatlar bugüne kıyasla kabul küçük kabul edilebilecek yolculuk rakamlarıyla limitlerine ulaşmışlardır. Aynı zamanda; bir başka bakış açısıyla, o gün ki demiryolu sistemleri ve teknolojisi düşünüldüğünde, hem yük hem yolcu trenleri, o günün düşük taşıma kapasiteleri dâhilinde aynı hat üzerinde ișletilebiliyorlardı. Ardından; hızlı ekonomik kalkınma dâhilinde artan trafik talebiyle Tokyo-Aichi kesiminde ve TokyoOsaka kesiminin her ikisinde de 2009 itibariyle günlük yolculuk sayısı 20.000'lere ulașmıștır. 1962'de mevcut Tohoku, Sanyo ve Joetsu Shinkansen hatlarının yerine çalışan konvansiyonel hatlarda günlük 1000-3500 aras1 yolcu taşınmış olup bu rakam mevcut Tokaido Shinkansen'den önce işletilen konvansiyonel demiryolu hatlarınınkinden oldukça düşüktür [8]. Japonya, bu Shinkansen hatlarını, Tokaido Shinkansen'i inşa ettikten birkaç yıl sonra inşa etmiştir. Bu hatlardaki günlük yolculuk sayısı, bugün iki veya dört katı kadar artış göstermiştir. Gayri Safi Milli Hâsıla (GSMH) ile şehirlerarası günlük yolculuk sayısı arasındaki ilişkiye bakıldığında, Japonya'nın bu hatlardaki yolculuğun 5000-6000'nin üzerine çıktığında ve Gayri Safi Milli Hasıla's1 (GSMH) 10.000- 
15.000 A.B.D. Dolarına çıtığında Tokaido Shinkansen'i inşa etmeye başladığı görülmektedir [8].

\section{Uygulama ve Başarımlar}

Japonya'dakine benzer bir şekilde Fransa'da da stratejik, taktik ve politik unsurların kayda değer bir yer tuttuğu açık ve belirli bir yüksek hızlı demiryolu (YHD) planına sahiptir. Fransa yüksek hızlı tren işleminide hız bazlı olaraktan 1954'te $243 \mathrm{~km} / \mathrm{saat}, 1955$ 'te $331 \mathrm{~km} / \mathrm{saat}, 1988$ 'de 408 $\mathrm{km} / \mathrm{saat}$, 1990'l1 y1llarda ise $515 \mathrm{~km} / \mathrm{saat}$ değerlerini bulan rekorlar kaydetmiş olup böylelikle hızlı demiryolunda bir marka teşekkül etmiştir. Fransa Nisan 2007 tarihinde de yeni bir rekor kaydetmiş olup $574,8 \mathrm{~km} / \mathrm{saat}$ değerinde bir hıza ulaşmıştır. Ancak aynı derecedeki bir kaite düzeyini Fransa'nın yüksek hız altyapıları için söylemek mümkün değildir. Ağ uzunluğu bağlamında ise 2009 itibariyle $1872 \mathrm{~km}$ hat ile Japonya'dan sonra ikinci sırada yer alıyordu. Bu inşa hatlarının birçoğu henüz 1976 Demiryolu Master Planı'nda konulan 2000 y1lı hedefleridir. Paris'i merkezine alan ve Fransa geneli ile bölge ülkelerine yaygınlık gösteren bir ağ geliştiren TGV (Train à grande vitesse_yüksek hızlı tren)olgusunun ortaya çıktığı görülmektedir. $\mathrm{Bu}$ bağlamda, $1000 \mathrm{~km}$ mesafelere kadar havayoluna göre daha rekabetçi bir ulaştırma türü olan yüksek hızlı demiryollarının ülkeye-bölgeye sağladiğ1 entegrasyon-refah-konfor-sosyal dağılım-erişilebilirlik gibi imkanların ne denli olabileceğini Fransa örneği ve TGV üzerinden okumak mümkündür. Fransa yüksek hızlı demiryolu olan TVG, ülkenin Akdeniz kıyısına, güneydoğusuna, Atlantik kıyısına, kuzeyine ve doğu yakasına hizmet götürmekte olup buna göre LGV (lignes à grande vitesse_yüksek hızlı hatlar) Atlantique, LGV Mediterranee, LGV Nord gibi isimler almaktadır. Atlantik hattı Atlantik Okyanusu kiyısınca İspanya'ya kadar bağlanacaktır. Benzer şekilde kuzey hattı LGV
Nord adı altında Paris'ten başlayarak Brüksel üzerinden Belçika'ya ulaşmaktadır.

Manş Tüneli'nin yapılmasının akabinde LondraParis arası mesafenin kısalması ile birlikte ulaşılan zaman tasarrufu değerleri ise \%50'leri bulmuştur [9].

Bunun daha da üzerindeki zaman tasarrufları ise Londra ile Brüksel arası yolculuklarda kaydedilmiştir. Ayrıca bunun yanı sıra yolculuk süresi tasarrıflarının da kendi içerisinde değiştiği görülmektedir. Bu bağlamda Büyük Britanyada kıyı hattında ve Köln ile Frankfurt arasında aktarmalar da dâhilinde erişilen yolculuk süresi kazanımları ise $\% 30$ ile $\% 60$ arasındaki değerleri bulmaktadır. İspanya'nın Sevilya kentinde 1992 yılında düzenlenen küresel ölçekli ticaret fuarı ile ülkenin kültür merkezi ve en büyük kentlerinden birisi sayesinde İspanya'da yüksek hızlı demiryolu hattı kurulum süreci başlatılmıştır. $\mathrm{Bu}$ doğrultuda kurulum ilk aşamada başkent Madrid ile ülkenin diğer önemli kentleri Barselona, Valensiya ve Sevilya'yı ihtiva etti. Bu ülkede 1992 yılında başkent Madrid ile Endülüs bölgesinin büyük kenti Sevilya arasında açılan hat ilk yüksek hızlı demiryolu (YHD) hattı olmuştur. Bunun akabinde ise geçen yıllar içerisinde İspanya'da AVE şirketi dâhilinde bu ulaştırma türüne ciddi yatırımlar yspılmış olup kuzeybat1 ekseninde Madrid-Vallodolid, güneydoğu aksında Madrid-Malaga ve doğu hat boyunca da Madrid-Barselona hatları tamamlanıp hizmete alınmıştır. Takibindeki birçok yatırımla İspanya yüksek hızlı demiryollarında (YHD) dünyanın lider ülkelerinden birisi olmuştur. Bundan da öte, gerçekleştirilmesi planlanan yatırımlar ile birlitek bu alanda dünyada zirvede yer alma şansına da sahip görünmektedir [10].

İspanyol şirketi Talgo'nun geliştirdiği tren setine göre değişebilen gabari malzemelerinin gelişimiyle birlikte Fransa'ya ve daha ötesine trafik yönelmesinin önü açılmış fakat bu sınırlı bir şekilde gerçekleşmiştir. 
Kapsamlı bir demiryolu planı 1987'de hazırlanmış olup 1993, 1997 ve 2005'te takip eden planlar hazırlanmıştır. Standart gabarili yeni hatların inşası kararı alınmış ve bunun ilki 1992'de Madrid-Sevilya arasındaki 471 km'lik hatta uygulanmıştır (Wong vd., 2000). Avrupa'da Belçika ve Hollanda, PBKAL (ParisBrüksel-Köln-Amsterdam-Londra yüksek hızlı demiryolu) hizmetlerini genişletici yatırımlar yapmakta olup, İsviçre, Portekiz ve İsveç'te aynı zamanda yeni yüksek hızlı demiryolları (YHD) Hatları planlamakta ve inşa etmektedir. Yüksek hızlı demiryolları, Avrupa Birliği sathında yolcu taşımacılığından yaklaşık \%25'lik bir paya ulaşmış bulunmaktadır.

Açıkça da görülmektedir ki gerekli ekonomik kalkınma düzeyine ulaşıldığında yüksek hızlı demiryolu yatırımları başlamakta olup Avrupa, Tayvan ve Güney Kore'denbu tablo net olarak okunmaktadır. Ancak diğer taraftan ise Çin ve Japonya'da ise kalkınmanın daha erken düzeylerinde iken yüksek hızlı tren yatırımlarının başladığı anlaşılmaktadır.

Buradan da açıkça anlaşılmaktadır ki koşullar elverdiği takdirde bu ulaştırma türündeki yatırımların başlangıcının nispeten daha öne alınması mümkün olabilmektedir. Muhtelif ülkelerden verilen örneklere bakıldığında farklılaşan tablolarla karşılaşılmaktadır. Şekil 2'de ise bu bağlamda ülkelerin yüksek hızlı demiryolu (YHD) hat yatırımlarına başladıklarındaki gayri safi yurtiçi hâsıla (GSYİH) düzeyleri gösterilmektedir [11].

Referans oluşturma amacıyla; 2007'de Fransa'da yürütülen uygun sayım verileri kullanılarak, ülke genelindeki 117 kişi $/ \mathrm{km}^{2}$ 'lik nüfus yoğunluğuna karşın $181 \mathrm{kişi} / \mathrm{km}^{2}$ 'lik bir nüfus yoğunluğuna sahip olan LGV Sud-Est (Güneydoğu) Hattı'nın geçtiği kesimde hesaplama yapılmıştır. Japonya ve Çin' den farklı olarak; ülke genelindeki farklı bölgelerde ve yüksek hızlı demiryolu hatlarının geçtiği bölgeler boyunca, büyük oranda bir nüfus yoğunluğu

farklılaşması

ile karşılaşılmamaktadır. Şekil 3'te ise nüfus yoğunluğu ve gayri safi yurtiçi hâsıla (GSYİH) bazlı olarak karşılaştırmalar sunulmaktadır [12].

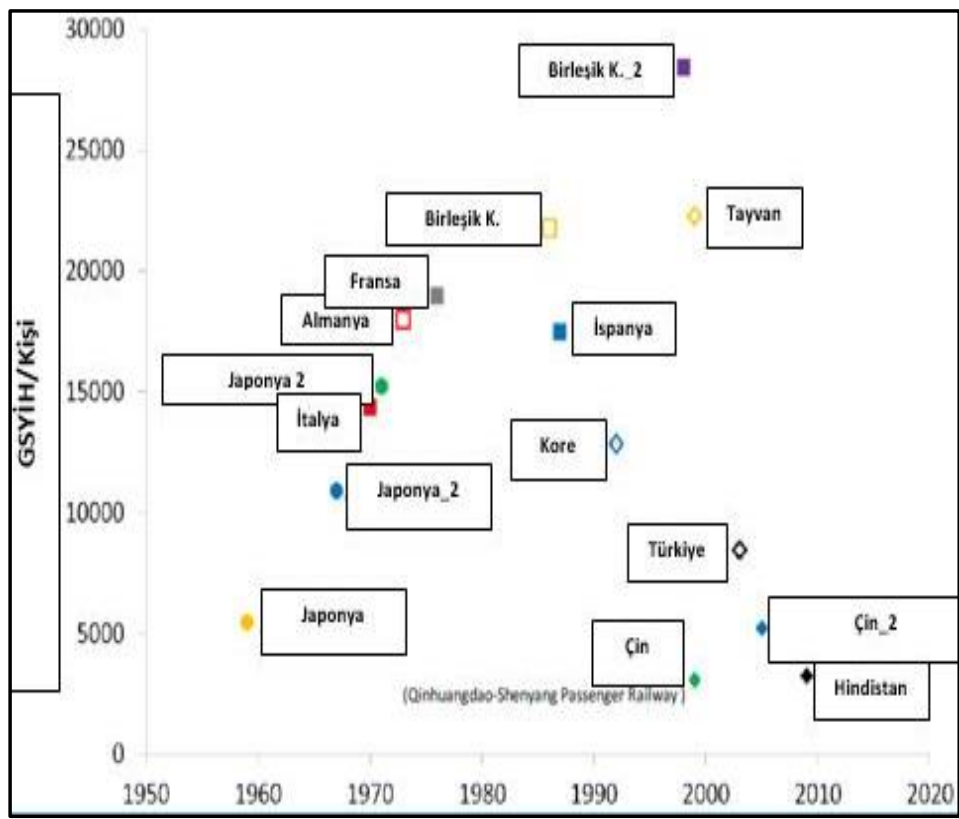

Şekil 2: Ülkelerin Yüksek Hızlı Demiryolu (YHD) Yatırımına Başladıkları Yıllardaki Gayri Safi Milli Hasılaları (GSMH) [11]

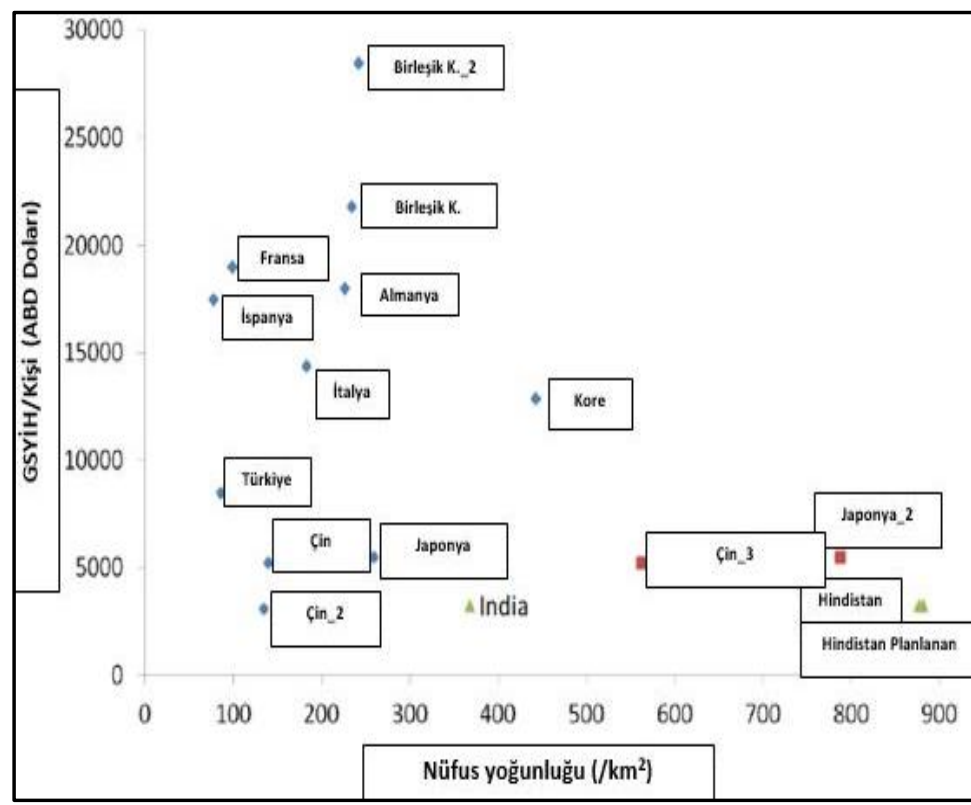

Şekil 3: Yüksek Hizlı Demiryolu Yapımına Başlandı̆̆ Y Ylda Nüfus Yoğunluğu-Gayri Safi Milli Hâsıla İlişkisi [12]

Hindistan; hızlı ekonomik gelişim gösteren ülkeler arasına girmiş olup ve büyüme eğiliminin 
devam edeceği görülmektedir. Çeşitli araştırma enstitülerinden edinilen verilere göre Hindistan'in 2030'a kadar yıllık ortalama \%8'lik büyüme gerçekleştirmesi öngörülmektedir. $\mathrm{Bu}$ öngörü göz önüne alındığında ve Hindistan'ın milli geliri nüfusuna bölündüğünde, 2015 için 4.000 ABD Doları bir Gayri Safi Milli Hâsıla, 2020 için 5.000 ABD Doları ve 2030 için 10.000 ABD Doları bir Gayri Safi Milli Hâsıla hesaplanmaktadır. Şekil 4'te ise Hindistan'da yıllara göre gayri safi yurtiçi hâsıla (GSYİH) durumu gösterilmektedir [13].

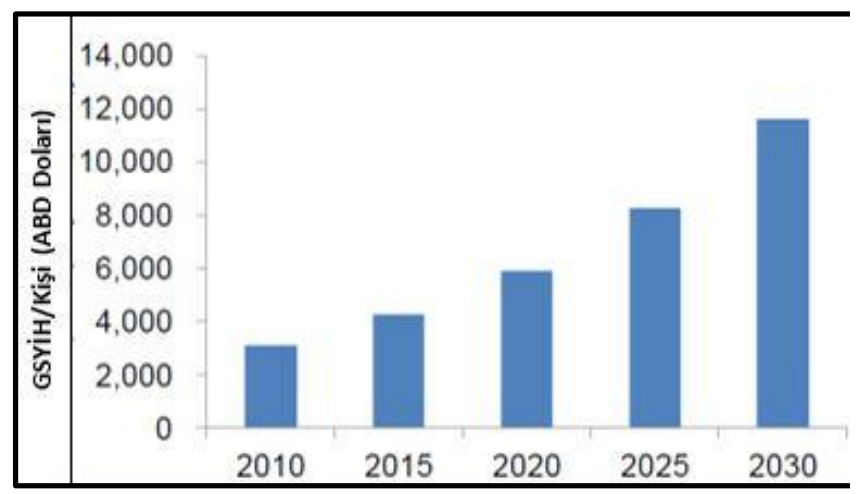

Şekil 4: Hindistan'a Yıllara Göre Tahmini Gayri Safi Milli Hâsıla [13]

Hindistan'1n 2011 itibariyle nüfus yoğunluğu $368 \mathrm{kişi} / \mathrm{km}^{2}$ olup dünyanın en yüksek nüfus yoğunluğuna sahip ülkesi olduğu görülmektedir. Bu; Japonya'nın nüfus yoğunluğundan (2010' da $337 \mathrm{kişi} / \mathrm{km}^{2}$ idi) daha yüksek bir değer olup Hindistan için nüfus yoğunluğunun en önemli kıstaslardan biri olduğu görülmektedir. Ayrıca Hindistan; Mumbai (Bombay)-Ahmedabad, Chennai-Bangalore gibi oldukça nüfus yoğun koridorlara sahiptir. $\mathrm{Bu}$ bölgeler; ülke genelindeki nüfus yoğunluğunun üzerinde bir yoğunluğa sahip olup bu değer Çin ve Japonya'nın yüksek hızlı demiryolu yapımına başladığ1 yıllardaki nüfus yoğunluğu ile örtüşmektedir.

Dolayısıyla Hindistan; gerek nüfus yoğunluğu ve gerekse de Gayri Safi Milli Hâsıla olarak yüksek hızlı demiryolu yapımına birkaç yıl içerisinde girmek için yeterli koşulları sağlamaktadır.
Ayrıca; Şekil 5'te de görüldüğü üzere Hindistan'ın birçok şehri 1 milyon ve üzerinde nüfuslara sahiptir. Hindistan' da milyonluk nüfusa sahip şehirlerin sayısı 2001'de 25 iken 2011'de 46'ya yükselmiştir. Bu sayı takip eden yıllarda daha da artmıştır. Dahası; Hindistan' da bazı bölgelerdeki şehirler zonlara ayrılmış olup yüksek hızlı demiryolu yapımına daha uygun hale gelmiştir [41].

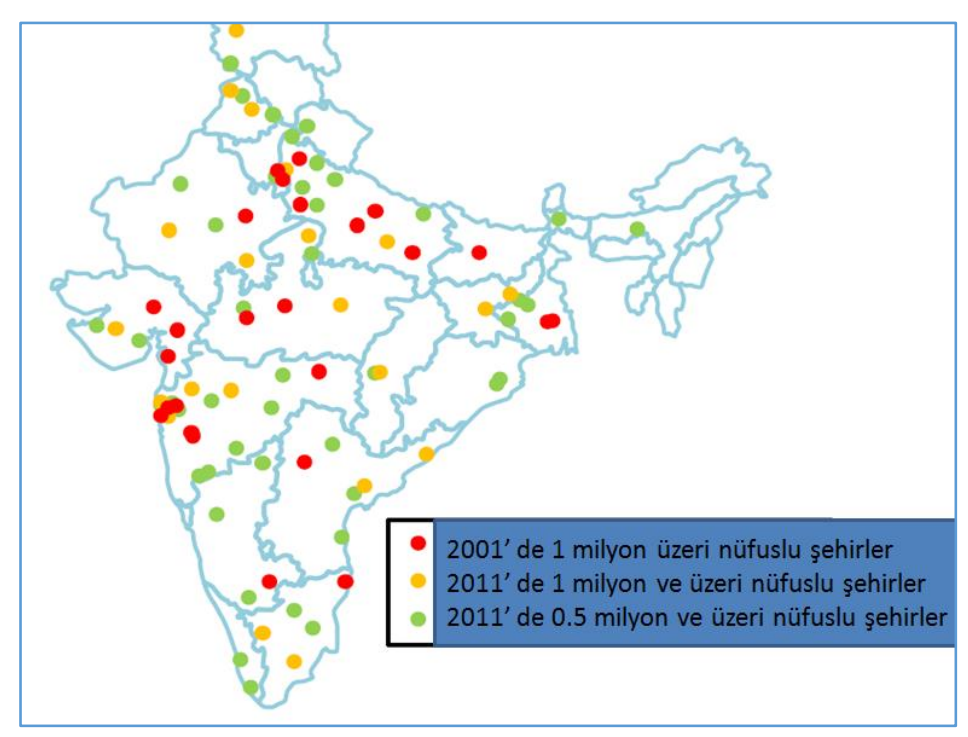

Şekil 5: Hindistan'da Nüfusu 500.000 ve Üzerinde Olan Şehirlerin Dağılımı [14]

\section{Sonuçlar ve Tartışma}

Yüksek hızlı demiryolları (YHD) mevcut konvansiyonel demiryolu (KD) altyapısının iyileştirilmesi ile de yeni bir yüksek hızlı demiryolu (YHD) altyap1 tesisi ile de gerçekleştirilebilmektedir. $600 \quad$ kilometre mesafelere kadar yüksek hızlı demiryolları (YHD) havayolu yolcu taşımacılı̆̆ına (HYT) nazaran daha rekabetçi görünmektedir. $\mathrm{Bu}$ kapsamda söz konusu iki ulaştırma türünün birbiri ile rekabetçilik unsurunun yanı sıra birbirini tamamlayıcı özelliği de göz önüne alınmalıdır. Zira entegrist bir yaklaşım daha doğru olacaktır. Öyle ki bütünleyici bir anlayışın olmadığ 1 yerlerde kimi hatlarda havayolu yolcu taşımacılığı (HYT) kimi yerlerde ise yüksek hızlı demiryolları (YHD) piyasadan çekilmektedir. Bu birçok zaman doğru sonucu vermeyebilmektedir. 
Bunun yerine, Avrupa'da Charles De Gaulle (CDG) havalimanında da görüldüğü üzere yüksek hızlı demiryolları (YHD) havaalanını besleyici hizmet görebilir. Böylesine bir bütünleşmenin yakalandığı ortamlarda bölgesel ziyaretler için en uygun vasat yakalanmış olacaktır. Örneğin birbirine komşu her ile havaalanı yapmak doğru çözüm olmayacaktır. Bunun yerine bölgesel merkez olan ile havaalanı yapıp, bölgenin diğer kentlerini bir yüksek hızlı demiryolu (YHD) ağ i ile birbirine ve havaalanına bağlamak sureti ile elverişli çözüm yakalanabilir. $\mathrm{Bu}$ da bölgeyi ziyarete gelen bir turistin bütün bir bölgenin önemli yerlerine seyahat imkânını yakalamasını sağlayacaktır [15].

İfade edildiği üzere yüksek hızlı demiryolları, hat rehabilitesi yapılmış kimi konvansiyonel altyapılar üzerinde de işletilmektedir. Dolayısı ile takip eden yıllarda bu şekli ile işletimde olan bir yüksek hızlı trenin araç ve ekipman yenilemesinde, üzerinde işletim gerçekleştirilen iyileştirilmiş konvansiyonel altyapının varlığı ve gereksinimleri ile adaptasyon kapasitesi de göz önünde bulundurulmak durumunda kalınmaktadır.

Hâlihazırda konvansiyonel hatları altyapısının iyileştirilmesi ile yüksek hızlı demiryolu (YHD) hat işletimine başlayan hatlar ise bu söz konusu toplam hatların \%30'unu teşkil etmektedir. $\mathrm{Bu}$ bağlamda hat işletiminde yüksek hızlı demiryolu (YHD) hız alt limiti olarak $250 \mathrm{~km} / \mathrm{saat}$ olarak alınırsa ve de münhasıran yüksek hızlı demiryolu (YHD) hat alyapısı esas alınır ise bu anlamdaki hat uzunluğu dünya genelinde 8500 km'den fazla görünmektedir [16].

Avrupa Birliği'nde demiryollarına, sürdürülebilirlik çerçevesinde son on y1lda ciddi bir eğilme söz konusudur. Kitada 2030 ve 2050 yıları projeksiyonlarında demiryollarının çok büyük türel dağılım oranlarına sahip olması beklenmektedir. Benzer bir eğilim, aynı periyotlarda aynı oranlara ulaşmamak kaydıyla, ivmelenme olarak Türkiye'de de söz konusudur [17].

Türkiye; 2023 Vizyonu doğrultusunda hedefler ortaya koymuş olup bunların en önemlilerinden biri 'Dünyanın en büyük 10 ekonomisi arasına girme' hedefidir. Türkiye; sahip olduğu kültürel sosyal politik ve benzeri parametreler bakımından ekonomik olarak hem büyümek zorundadır ve hem de ekonomik büyümeyi gerçekleştirebilecek dinamizm ve potansiyele sahiptir [18]. Ülkemizde son yıllarda gerçekleştirilen yatırımlar, tartışılmakla beraber, genel anlamda ekonomik büyümeyi destekleyici işlev görmüştür. Dolayısıyla 2023 Vizyonu çerçevesinde ortaya konmuş olan ekonomik büyüme hedefleri, Ulaştırma Sektörü Hedefleriyle (dolayısıyla Şehirleşme ve Şehirlilik olgusuyla) doğrudan bir ilişki içerisindedir [19]. Ekonomik kalkınma; sorunlarını en aza indirmiş ve verimli-işler bir ulaştırma sisteminin kurulumundan bağımsız düşünülemez. Yolcu ve yükün en yüksek kapasite ve hizmet parametreleriyle taşınmasının sağlanması, belirli bir ekonomik ve teknik kalkınmışlık düzeyini gerektirirken, sorunlarını en az indirmiş, verimli, entegre, sürdürülebilir ve kapasiteli bir ulaştırma sektörü de, ekonomik kalkınmanın-hem nitel ve hem de nicel olarak- en üst düzeyde sağlanmasını beraberinde getirecektir [20].

\section{Teşekkür}

$\mathrm{Bu}$ çalışmada, bugüne kadarki mesai hayatımızda desteklerini esirgemeyen, birlikte çalıştığımız mesai arkadaşlarımıza teşekkür ederiz.

\section{Kaynaklar}

[1] Chen, C., \& Hall, P. (2011). The impacts of highspeed trains on British economic geography: A study of the UK's InterCity 125/225 and its effects. Journal of Transport Geography, 19(4), 689-704. doi:10.1016/j.jtrangeo.2010.08.010

[2] Abrahams, G. (2014). What 'is' territorial cohesion? What does it 'do'?: Essentialist versus pragmatic approaches to using concepts. European Planning 
Studies, 22(10), 2134-2155. Doi: 10. 1080/09654313.2013.819838

[3] Brezzi, M., \& Veneri, P. (2015). Assessing polycentric urban systems in the OECD: Country, regional and metropolitan perspectives. European Planning Studies, 23(6), 1128-1145. Doi: 10. 1080/09654313.2014.905005

[4] Arduin, J. P., \& Ni, J. 2005. French TGV network development. Japan Railway \& Transport Review. 40(3), 22-28.

[5] Kızıltaş, M.Ç., Altan, M.F., 2018, A Review in Term of Service Parameters On the Modal Choice sand Mass Transport, İzmir

[6] Altan M.F., Kızıltaş M.Ç., 2019, Yüksek Hızlı Demiryolları, Yolcu Ve Yük Taşımacılığı Karşılaştırmaları Bağlamında Küresel Ölçekli Bir Derleme Çalışması, Dicle Üniversitesi Mühendislik Fakültesi Dergisi, ULAKBİM (yayın aşamasında)

[7] Tapiador, F. J., \& Martí-Henneberg, J. 2009. Potential economic impacts of technological and organizational innovations in intermodal access to major passenger terminals. In 18th International Symposium on Transport Economics and Policy. p. 409.

[8] Takatsu, T. 2007. The history and future of highspeed railways in Japan. Japan Railway \& Transport Review, 48, 6-21.

[9] Sutherland, D., Araujo, S., Égert, B., \& Kozluk, T. J. 2009. Infrastructure investment: links to growth and the role of public policies.

[10] Liu, Y., Zhang, X., Zeng, J., Zhang, X., Zhang, P., \& Zhong, Z. 2007. Technology of Sound Intensity Theory in High Speed Railway Car Noise Controlling. In International Conference on Transportation Engineering. pp. 1243-1248.
[11] Altan, M.F., Kızıltaş, M.Ç., 2018, Toplu Taşımada Çok Amaçlı Karar Verme ve Metropolitan Bir Alanda Ev-İş Ulaşım Hizmeti Modellemesi, Karaelmas Fen ve Mühendislik Dergisi, ULAKBİM

[12] Spaven, D. 2006. Are High-speed railways good for the environment? Transform Scotland, Edinburgh, 3.

[13] Anderson, J. E., \& Van Wincoop, E. 2004. Trade costs. Journal of Economic literature, 42(3), 691751.

[14] Van Oort, F., McCann, P., 2009. Economic growth in cities and urban networks. In: KochendörferLucius, G., Pleskovic, B. (Eds.), Spatial Disparities and Development. The World Bank, Washington DC, pp. 91-108.

[15] Vasanen, A. (2012). Functional polycentricity: Examiningmetropolitan spatial structure through the connectivity of urban sub-centres. Urban Studies, 49(16), 3627-3644. doi:10,1177/ 0.042.098.012.447.000

[16] Combes, P. P., Mayer, T., \& Thisse, J. F. 2008. Economic geography: The integration of regions and nations. Princeton University Press.

[17] T.C. Ulaştırma Bakanlığı. 2010. "Hedef 2023" 10. Ulaştırma Şurası, şura raporu, Ankara

[18] Wong, W. G., Han, B. M., Ferreira, L., Zhu, X. N., \& Sun, Q. X. 2002. Evaluation of management strategies for the operation of high-speed railways in China. Transportation Research Part A: Policy and Practice, 36(3), 277-289.

[19] T.C. 10. Kalkınma Planı Ulaştırma ve Trafik Güvenliği Ö.İ.K. Raporu, 2012, Ankara

[20] Kızıltaş, M. Ç., 2014, 'Yüksek Hızlı Demiryolu Politikaları - 1' http://www.ulastirmadunyasi.com/?p=824 (01.11.2014) 